\title{
The Effects of Job Crafting on Career Success of Multinational Corporations' Employees
}

\author{
Kyung-Hee YOON ${ }^{1}$, Bo-Young KIM ${ }^{2}$, Jae-Gun EOM ${ }^{3}$
}

Received: July 27, 2019 Revised: September 16, 2019 Accepted: September 24, 2019

\begin{abstract}
As the recent tendency of career management has changed, companies have supported progressive career management and development of their employees internally. And strengthening job crafting is an effective activity not only to improve the work efficiency of the organizations but also to improve the job satisfaction and wellbeing of their employees. In these backgrounds, this paper aims to explore the components of job crafting for the multinational employees in order to emphasize the importance of job crafting and empirically analyze the influential relationship in terms of career success through career commitment and career attitude. Based on literature review the job crafting was defined with three components; task crafting, relation crafting, and cognitive crafting. A total of 336 survey data were analyzed for a total of 27 multinational corporations. As the analysis result the task crafting and cognitive crafting of multinational employees were shown to have an influence on career attitude, but relation crafting did not have any impact on career. It can be interpreted that the employees have self-directed career attitude through a method of showing visible performance based on their given jobs rather than having individual career management attitude through relationships between departments, organizational members, and supervisors.
\end{abstract}

Keywords : Job Crafting, Career Attitude, Career Commitment, Career Success, Multinational Corporations

JEL Classification Code : M11, M16, M50, M53

\section{Introduction}

Recently, as the industrial and occupational environments have rapidly changed around the world, there have been a lot of changes in past personnel managements and strategic administration approaches. Today, knowledge and competence within an organization should be affirmatively utilized as being shared with employees, not owned by the organization, and the organization should be able to support individual career management and

1 First Author, Professor for special appointment, Ewha Womans University, South Korea. Email: kayyoon@ewha.ac.kr

2 Corresponding Author, Associate Professor, Seoul Business School, aSSIST, South Korea. [Postal Address: 46 Ewhayeodae2-gil, Seodaemun-gu, Seoul, Korea, 03767] Email: bykim2@assist.ac.kr

3 Adjunct Professor, Duksung Women's University, South Korea. Email: 01027154370@naver.com

(c) Copyright: Korean Distribution Science Association (KODISA)

This is an Open Access article distributed under the terms of the Creative Commons Attribution Non-Commercial License (http://Creativecommons.org/licenses/by-nc/4.0/) which permits unrestricted noncommercial use, distribution, and reproduction in any medium, provided the original work is properly cited. qualitative improvement of life through the individual competence reinforcement of employees (American Training and Development Conference, 2019). Especially, in the rapidly changing digital-based business environment, the interest in personal career management, rather than organizational dimension, began to strongly appear in the various organizational cultures, which are created in the communication between the Millennium generation and the older generation, and the relationship with people that is more complicated by the change of organizations, the job change due to social influence, and SNS, while the organizational members of past companies have strongly demanded organizational commitment, organizations' creating performance, loyalty for the organizations, and the need for social recognition through their loyalty (Lent, Ireland, Penn, Morris, \& Sappington, 2017).

In this changes, career management had emphasized crucially more in the terms of active and spontaneous selfdevelopment by organizational members themselves, beyond the purpose of improving work efficiency through the competence reinforcement of employees (Dries, Van 
Acker, \& Verbruggen, 2012). In particular, as getting into the global low-growth era and reducing the opportunities for individuals to change their jobs for career management, the recognition and paradigm of career management within the organizations have spread, not about personal career management for changing their jobs (Lim, 2016). Therefore, new concepts such as boundless careers and Protean careers have been introduced, and job crafting, defined as a series of activities that employees change their works given in the workplaces themselves so make the jobs meaningful, has also emphasized in this context (Wrzesniewski \& Dutton, 2001; Lim, Ha, Oh, \& Son, 2014).

Therefore, the career success of organizational members is now expressed in terms of psychological satisfaction that brings positive effects on the developments of individual qualities and careers by accumulating personal job performances and job experiences (Adya \& Kaiser, 2005), beyond the means of, based on the continuity of the work experience within the organizations, drawing successful results (Evers \& Sieverding, 2014) and measuring efficient job developments (Seibert \& Kraimer, 2001). Moreover, the employees of multinational corporations have a strong individual-centered organizational culture than general local companies, and they progressively respond to personal career development and management than the members of organizations. Multinational corporations are open to the external labor market due to the influence of the country, where their headquarters are located, and their employees do not feel the risk of changing jobs because the companies approve all of personal careers although employees modify their jobs; therefore, the attitude of boundless careers in the open employment conditions was revealed to be higher than the members of general corporations (Lee \& Lee, 2015).

Accordingly, the multinational corporations prioritize open and flexible personnel strategies in human resource management, and organizational members are required to initiatively manage their careers in various job experiences, capacity development, and advanced skill learning (Lim, 2016). In addition, for the multinational organization members, they can be more proactive toward personal career management with the impacts of the open organizational culture of headquarters and the environment of flexible human resource management, and their personal characteristics can be strongly appeared in the aspect of career management (Kostova \& Roth, 2002). Therefore, being initiative and voluntary to the multinational employees than general companies, job crafting can have a greater impact on the career management of employees. However, there are few researches on the organizational culture and members of multinational corporations, and the studies considering detailed features have restrictive limits especially in the case of job crafting. In this study, in order to emphasize the importance of job crafting and empirically analyze the influential relationship in terms of career success, it aimed to explore the components of job crafting for the multinational employees.

\section{Literature Review}

\subsection{Job Crafting}

Job crafting implies a series of activities that make jobs more meaningful by spontaneously modifying the works given to an individual, which are the physical and cognitive changes in one's works or the related sector to one's works, while the individual does not limit the working scope given on the job description (Wrzesniewski \& Dutton, 2001). Job crafting is also an action of reducing factors that can have a negative influence on the individual beyond increasing the one's workload or deepening the relationship with people (Lyons, 2005). In other words, job crafting includes that the individual actively changes the environmental demands and available resources in addition to the resources possessed by the person. Meanwhile, Tims and Bakker (2010) considered job crafting as an action of balancing between the job demands and resources given to people within their capabilities and needs.

Recently, companies have pursued the achievement of organizational goals by expanding the role of each organizational member through the job-oriented personnel management and the manpower administration-specialized personnel management. As a result, top-down job crafting process has spread focusing on effective job distribution and design (Campion \& McClelland, 1993). With such changes in the organizations, their employees also have concentrated on productivity improvement through their self-directed and voluntary job crafting (Black \& Ashford, 1995; Grant \& Ashford, 2008). Also, the concept of 'job crafting' was generated in the job modifications of bottom-up method rather than top-down method, which defines a process of making one's given jobs or tasks significant by oneself (Wrzesniewski \& Dutton, 2001; Lim et al., 2014). Even though the given jobs are similar, not limited to the given job descriptions, it is an activity to recognize and adjust the works through the relationship with others (Berg, Dutton, \& Wrzesiewski, 2008), which means the voluntary job design of organizational members with their activeness, autonomy, and positiveness, not directed job crafting by organizations.

The job design or work design in the past was recognized as passively managing given tasks according to the organizational structure of companies or the boss in organizations. If job design is to do the tasks on the given job description in the organization, job crafting can be said that organizational members creatively and initiatively progress their jobs themselves in the changes of their works (Griffin, Neal, \& Parker, 2007). As the previous research related to the job crafting with the satisfactions of job and career, there is a study on job satisfaction and job characteristics through job crafting, which shows that the job commitment and satisfaction are higher when transportation officers, rather than administrators, do the job redesign (Ilgen \& Hellenbeck, 1992). In addition, Yan, Su, Wen, and Luo (2017) asserted that personal characteristics, 
core-self-evaluation, and initiative job design gave an influence on job satisfaction. Kim and Beehr (2018) empirically stated that self-directed job design behaviors strongly had influence by the perceived supervisory support of supervisors in job crafting.

Today, employees in organizations have been increasingly interested in job crafting that actively modifies their task boundaries (Demerouti, Bakker, \& Gevers, 2015). Job crafting means that organizational members positively adjust the scope and connection of their works or change the perception of their works, not limiting their task boundaries given on the job description. Job crafting is known to improve the significance and identity of job, job satisfaction and organizational commitment (Ghitulescu, 2013), psychological wellbeing (Berg et al., 2008), person-job fit (Tims \& Bakker, 2010), and the pleasure and performance of work (Tims, Bakker, \& Derks, 2015).

\subsection{The Components of Job Crafting, Career Attitude, and Career Commitment}

The previous researches of job crafting have mainly focused on personal characteristics with the types of job crafting (Lim et al.,2014; Grant, Parker, \& Collins, 2009) or concentrated on the positive outcomes of job crafting (Berg et al., 2008; Tims et al., 2015). Therefore, it can be seen that the understanding of antecedents of job crafting is lacking. This is because, as job crafting originally means the behaviors of organizational members to initiatively change their task boundaries, there is an aspect that is judged the personal characteristics of job crafters, the subjects of job crafting, are more important than external situational factors (Berg et al., 2008).

However, it has been empirically found that recent job crafting predicts such intrinsic motivational needs (Slemp \& Vella-Brodrick, 2013), and it has suggested the researches on the connection of job crafting with job characteristics, the relational context within organizations (Ghitulescu, 2013), trust, authentic leadership (Kim \& Shim, 2012), team cohesion (Park, 2015). This is because that it is easier for organizations to change their work environment than personal characteristics when they try to promote the job crafting of their employees.

Tims and Bakker (2010) defined job crafting, based on the model of job demand-resource, as an action that people balance job demands and job resources within their capacities and requires, and they subdivided it into four subdimensions through its factor analysis (Tims et al., 2015). The four sub-dimensions are increasing structural job resources, reducing obstructive job demands, increasing social resources, and increasing challenging job demands. Also, Kim et al. (2016) consider job crafting as a job-related activity that organizational members modify their works themselves regardless of the permission of others and believed that the attitude of others can promote or restrain job crafting when the employees change their jobs (Berg et al., 2010; Grant et al., 2009), so they, based on it, set up the roles of others as the situational antecedents of job crafting and suggest the role breadth self-efficiency as a psychological mechanism that connects job crafting with supportive supervision, co-worker trust, and work routinization.

Particularly, Wrzesniewski and Dutton (2001) suggest the modification of three parts, which are task boundaries, relational boundaries, and cognitive boundaries, as the components of job crafting. The modification of task boundaries is to switch the physical boundaries of jobs, such as the number or scope of tasks and the way and method of working, and the modification of relational boundaries is to change the boundaries of relationships and interactions with customers, supervisors, or colleagues who encounter at work. In addition, the modification of cognitive boundaries is to switch the boundaries of one's cognition about the purpose and significance of jobs.

In the researches on the relationship between the job crafting and careers, firstly Petrou, Demerouti, and Schaufeli (2015) introduced the result, which task and career commitment are related through job crafting. Also, there are studies arguing that job crafting is useful for leading career management of organizational members in a rapidly changing management environment (Ghitulescu, 2013; Petrou et al., 2015). Grant et al. (2009) and Seibet No Reference (2001) explained that job crafting was effective for the employees' commitment in the connection with organizational performance, career commitment, and compensation, and that job crafting gave opportunities for emotional stability, compensation, and promotion for organizational members who actively perform their job duties because job crafting was more useful in the perspective of individuals.

As a result, job crafting was revealed to be able to give a favorable effect on job commitment and job expansion (Dmerouti No Reference 2015), and it was also shown to have a positive influence on the work-home balance and the self-directed career success by job crafting (Akkermans \& Tims, 2017). Furthermore, according to the study results of Wrzesniewski, LoBuglio, Dutton, and Berg (2013), as the satisfaction of life is improved and personal resilience is found in the case of organizational members who have been doing job crafting, job crafting is not only significant at the organizational level but also useful in the job management and career attitude of employees, and this can be confirmed that the job satisfaction of organizational members can be advanced.

In particular, the self-directed career management showed the significant result, which job crafting had a positive relationship between the spontaneous career attitude and the intention to retire (Fried, Grant, Levi, Hadani, \& Slowik, 2007; De Vos \& Segers, 2013). In the research through reintegration of job design and career, the study on which parts could be helpful for career management was conducted (Hall \& Heras, 2010), and a research was also suggested that employees' calling gave a significant impact 
on career attitude and career satisfaction by job crafting and decreased their turnover intention (Ko, 2012).

Based on these previous researches, this study designed the following hypotheses that task crafting, relation crafting, and cognitive crafting, which were suggested by Wrzesniewski and Detton (2001) as the components of job crafting, had an influence on the career attitude of multinational employees.

Hypothesis 1: The task crafting of multinational employees has a positive(+) impact on career attitude.

Hypothesis 2: The relation crafting of multinational employees has a positive(+) impact on career attitude.

Hypothesis 3: The cognitive crafting of multinational employees has a positive $(+)$ impact on career attitude.

Also, this study aimed to examine the relationship between the components of job crafting and the career commitment along with career attitude. $\mathrm{Lu}$, Wang, $\mathrm{Lu}, \mathrm{Du}$, and Bakker (2014) and Bakker, Rodríguez-Muñoz, and Sanz-Vergel (2016) explored the various connections between job crafting and job commitment, and Chen, Yen, and Tsai (2014) suggested the influential relationship between job crafting and career commitment through the mediation of person-job fit. Job crafting can affect selfdirected personality and job performance through career commitment (Bakker, Tims, \& Derks, 2012), Kim and Beehr (2018) claimed that job crafting could have a major impact on career commitment. In particular, there are studies that low cognitive crafting has a negative impact on the connection between the leaders' calling and the job efficiency of employees, which makes it impossible to engage in career commitment (Park \& Sohn, 2018). In the case of Hur, Jung, and Kang (2019) they also confirmed the discriminatory influence on self-directed job crafting and career commitment as examining the behaviors between the empowering leadership, the job and organization commitments, and the organizational members in order to identifying the influence of actions in job crafting, and the result of their study suggested that individual self-efficiency and autonomy had a strong impact on job crafting, job commitment, and career commitment.

Consequently, it can be identified that job crafting can have diverse effects on psychological commitment influences of each organizational member such as organization commitment, job commitment, and career commitment. Therefore, this study suggests the hypotheses that job crafting components of multinational employees can give a positive influence on career commitment.

Hypothesis 4: The task crafting of multinational employees has a positive $(+)$ impact on career commitment.

Hypothesis 5: The relation crafting of multinational employees has a positive(+) impact on career commitment.
Hypothesis 6: The cognitive crafting of multinational employees has a positive(+) impact on career commitment.

\subsection{Career Attitude, Commitment Success, and Career Success}

Since career is related to individuals as long as they have a job for lifetime, the importance of career has been getting bigger today, when the employment relations are uncertain (Carson \& Bedeian, 1994). The researches on career have been highlighted in various disciplines, and there has been recently a growing interest in career management, career change, career outcome, and career success ( $\mathrm{Na}, 2015)$. Especially, career success is considered as the crucial achievements of career development activities so highlighted by career researchers (Pan \& Zhou, 2015). Career success refers to 'the positive psychological state and work-related output accumulated as the results of personal work experiences (Seibert \& Kraimer, 2001). Career success is divided into the objective career success, which the third parties can evaluate such as wage increase and promotion, and the subjective career success, which one assesses oneself as successful through one's experiences such as job satisfaction or career satisfaction (Abele \& Spurk, 2009). In the early stage of the research perspective, there were a lot of researches on objective career success, but the researches on subjective career success have been getting attention because the perspective of career success changed as a modern perspective of career appeared, such as boundless career and protean career (Doherty, Dickmann, \& Mills, 2011).

Among the factors influencing career success, career commitment, organization commitment, career attitude, and motivation have been mentioned (Kidd \& Green, 2006; Heslin, 2005). Especially, as emphasizing self-directed career management and career attitude for career success (Hall, 2002), self-directed career behaviors depend on career-related outcomes and personal disposition in many researches, which are explained by self-initiative career attitude, mentioning that these behaviors are manifested through the job transfer within and outside the organization or the current job improvement (Kossek, Roberts, Fisher, \& Demarr, 1998). As corporations became unable to guarantee their employees' lifetime jobs, individuals got forced to have the perception that they should be responsible for their own employment and career themselves (Arthur, Khapova, \& Wilderom, 2005). Individuals with high-educated and highskilled work experiences are relatively willing to gain better career opportunities, using their personal capital. Therefore, they have a lot of interest in enhancing employment possibility and organizational mobility with their job expertise, rather than thinking of retirement in their organizations (Baruch, 2001). These changes in career attitude are shown as career success such as the progressive shifts of workplaces or departments (Arthur \& Rousseau, 1996). It can be seen as a career attitude of building up 
experiences while shifting to various organizations and occupations without limiting one's career to one organization and occupation. Ultimately, the experiences of career success making them grow into a core talent can be attracted from the career attitude that is required as a flexible and adaptable talent in the management environment (Hallenbeck, 2016).

In addition, career success means positive works or psychological outcomes accumulated through the various experiences by individuals (Seiber \& Kraimer, 2001), and internal career success can imply the psychological success created by self-pride, through the personal achievement or the accomplishment of diverse goals (Gattiker \& Larwood, 1986; Akkermans \& Tims, 2017). Therefore, it is linked to career commitment, which means individuals' power of strong motivation in their selected jobs (Hu \& Bentler, 1999; Richardson \& Mallon, 2005), and the organizational members are more committed in their organizations and feel more career success when their organizational environments change and the direction of their careers are modified (Noordin, Williams, \& Zimmer, 2002). A research by Aryee and Chay (1994) found that career commitment and career success are more influential when the self-efficiency of employees is high. Career commitment affects subjective career satisfaction and objective wage level so works for enhancing the possibility of career success (Ballout, 2009).

Based on these previous studies, this research suggests the following hypotheses that the career attitude and career commitment of multinational employees also have a positive(+) impact on career success.

Hypothesis 7: The career attitude of multinational employees has a positive(+) impact on career success.

Hypothesis 8: The career commitment of multinational employees has a positive(+) impact on career success.

\section{Methodology}

\subsection{Research Model}

This study aimed to verify the effect of multinational employees' job crafting on career success through career commitment and career attitude. Therefore, based on the research hypotheses applying the three factors derived from the previous researches by Wrzesniewski and Dutton (2001), the conceptual model of this study was constructed as Figure 1 .

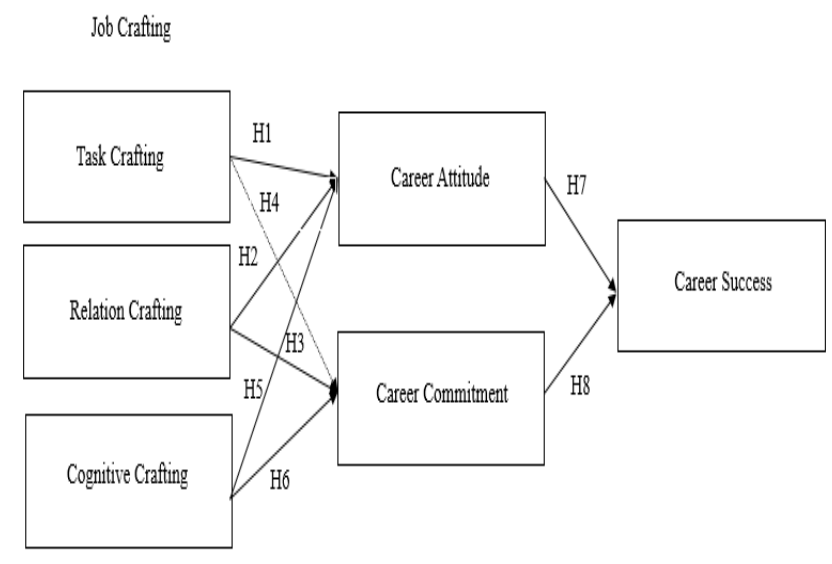

Figure 1: Research Model

\subsection{Variables and Analytics Approach}

The measure statements used in the survey were the Likert 5-point scale ( $1=$ Not at all, $5=$ Very yes), and based on the previous studies, the operational definitions and measure statements of variables were designed as Table 1 . The survey tool used in the measure of job crafting was JCQ-K (Job Crafting Questionnaire-Korea), which was validated by Lim et al. (2014) as Korean version of Job Crafting Questionnaire (JCQ) fully reflecting the three domains of W\&D developed by Slemp and Vella-Brodrick (2013).

First, the statements of task crafting are, "Try a new way of doing tasks better," "Change the scope and method of the given tasks to improve the completion of the job," "Take charge of tasks that make better use of my capabilities or new tasks that I am interested in," "I am also willing to take additional tasks that was not given to me," and "Do the tasks for my competence or interest, first." Second, the statements of relation crafting are, "At work, try to get along with customers, supervisors, and colleagues," "Organize or actively participate in social gathering related to the work," "At work, take the lead the events like the birthday parties of co-workers," "Become a mentor for a new employee, whether official or not," and "At work, take the lead the events like the birthday parties of co-workers." Third, the statements of cognitive crafting are, "Think about what my job means in my life," "Remind myself that my work is important for the success of our company," "Remind myself that my work is important for the development of our society," "Think about how my work can have a positive impact on my life," and "Reflect on what role my job plays for my happy life." A total 15 statements were measured, five for each domain, in the three components.

Career attitude was, as modifying and complementing with value orientation and self-direction that are career attitude measurement tools developed by Briscoe and Hall (2006), composed of 8 statements and measured: "Search the career to the personal priority than the employers'," 
"Follow my conscience if the company demands that I am against value," "My work value and career are more important than the needs of company," "When requesting what the company does not want, judge my career with my own value," "Look for my own career development opportunities although the company does not give me a chance for," "The success and failure of my career are under my responsibility," "My career management is myself," and "Ultimately, my career management depends on myself." In career commitment, four statements were extracted and applied for the research purpose from the measure statements used by Blau (1989): "I want to maintain my career in the profession that I belong to," "I keep working even though I have enough money," "I like to work so do not give up my job," and "I want to work with my lifetime job."

Lastly, four statements were used for career success, utilizing the sub-displacements used by Nam (2014), the employment possibility to measure career success, and the career satisfaction: "I am satisfied with my career so far," "I am satisfied with my career goals so far," "I am satisfied with the career for the economic goal fulfillment," and "I am satisfied with my career in the direction of meeting my goal of developing new skills."

Table 1: Variable Definitions

\begin{tabular}{|c|c|c|c|}
\hline Factors & Operational Definition & Item & Reference \\
\hline $\begin{array}{c}\text { Task } \\
\text { Crafting }\end{array}$ & $\begin{array}{l}\text { Processing tasks by } \\
\text { changing the physical } \\
\text { boundaries of tasks such as } \\
\text { the number and scope of } \\
\text { tasks and the way of } \\
\text { working. }\end{array}$ & 5 & \multirow{3}{*}{$\begin{array}{l}\text { Slemp and } \\
\text { Vella- } \\
\text { Brodrick } \\
\text { (2013) } \\
\text { Lim et al. } \\
(2014)\end{array}$} \\
\hline $\begin{array}{l}\text { Relation } \\
\text { Crafting }\end{array}$ & $\begin{array}{l}\text { Processing the } \\
\text { relationships with } \\
\text { customers, supervisors, } \\
\text { and colleagues. }\end{array}$ & 5 & \\
\hline $\begin{array}{c}\text { Cognitive } \\
\text { Crafting }\end{array}$ & $\begin{array}{l}\text { Reinterpretation of job } \\
\text { through self-awareness } \\
\text { about the purpose or } \\
\text { significance of the work. }\end{array}$ & 5 & \\
\hline $\begin{array}{c}\text { Career } \\
\text { Attitude }\end{array}$ & $\begin{array}{l}\text { Focus on personal values } \\
\text { and proactive behaviors for } \\
\text { career development and } \\
\text { management. }\end{array}$ & 8 & $\begin{array}{l}\text { Briscoe } \\
\text { and Hall } \\
(2006) \\
\text { Shin } \\
(2014) \\
\end{array}$ \\
\hline $\begin{array}{c}\text { Career } \\
\text { Commitment }\end{array}$ & $\begin{array}{l}\text { The degree of maintaining } \\
\text { the significance and } \\
\text { continuity of the career } \\
\text { goals that one has set. }\end{array}$ & 4 & $\begin{array}{l}\text { Blau } \\
(1989)\end{array}$ \\
\hline $\begin{array}{c}\text { Career } \\
\text { Success }\end{array}$ & $\begin{array}{l}\text { The job satisfaction and } \\
\text { career satisfaction of } \\
\text { competence, skills, and } \\
\text { career process for } \\
\text { achieving career goals. }\end{array}$ & 4 & $\begin{array}{l}\text { Nam } \\
(2014)\end{array}$ \\
\hline
\end{tabular}

\subsection{Data Collection and Analysis Method}

Focusing on multinational corporations that have entered in South Korea, mainly in Seoul and the metropolitan area, the data was collected as conducting the survey on a total of 394 people using online and direct collection survey methods from February $18^{\text {th }}-28^{\text {th }}, 2017$. For the data analysis, only 366 questionnaires were used for the survey analysis, except for 28 copies with insincere responses or missing values. SPSS 24.0 was applied for the descriptive statistics and normality of the demographic characteristics and variables of the data, and AMOS 22.0 was utilized as a structural equation model to identify the relationship between regression analysis and path analysis. Maximum Likehood Estimation (MLE) was used to measure coefficients, and Sobel test was conducted to verify the statistical significance of mediating effect in its indirect effect analysis because it was difficult to individually verify if one or more variables were included. This study was conducted by adding additional variables in the questionnaires used in the $2018 \mathrm{JABR}$, "The influence of Job Insecurity on Career Commitment and Attitude in Multinational Corporations."

\section{Analysis Results}

\subsection{Demographics of Respondents}

As a result of the survey, it was composed of 118 males and 248 females. The most common in 40s but it was relatively and evenly distributed by generation: 37 people under 30 years old, 126 people in 30s, 131 people in 40s, and 72 people over 50 years old. In the case of the subjects' academic background, the majority of subjects were college graduates: 21 high school graduates, 231 college graduates, 105 graduates with master degree, and 9 graduates with doctoral degree. HR accounted for a large portion of their jobs: 28 people working in R\&D, 8 in Production, 117 in Sales, 133 in HR, 39 in Finance, and 41 in Planning (Table 2). 
Kyung-Hee YOON, Bo-Young KIM, Jae-Gun EOM / Journal of Asian Finance, Economics and Business Vol 6 No 4 (2019) 213-225

Table 2: Demographic Information of the Survey Participant

\begin{tabular}{|c|c|c|c|c|c|c|c|}
\hline \multicolumn{2}{|r|}{ Class } & Frequency & $\%$ & \multicolumn{2}{|c|}{ Class } & Frequency & $\%$ \\
\hline \multirow{3}{*}{ Sex } & Male & 118 & 32.2 & \multirow{6}{*}{$\begin{array}{l}\text { Academic } \\
\text { Background }\end{array}$} & High School & 21 & 5.74 \\
\hline & Female & 248 & 67.8 & & Bachelor & 231 & 63.11 \\
\hline & Total & 366 & 100 & & Master & 105 & 28.69 \\
\hline \multirow{5}{*}{ Age } & $0 \sim 30$ & 37 & 10.11 & & Ph.D. & 9 & 2.46 \\
\hline & $31 \sim 40$ & 126 & 34.43 & & & & \\
\hline & $41 \sim 50$ & 131 & 35.79 & & Total & 366 & 100 \\
\hline & over 51 & 72 & 19.67 & \multirow{8}{*}{$\begin{array}{l}\text { Period of } \\
\text { Use }\end{array}$} & R\&D & 28 & 7.6502732 \\
\hline & Total & 366 & 100 & & Production & 8 & 2.1857923 \\
\hline \multirow{6}{*}{$\begin{array}{l}\text { Period } \\
\text { of } \\
\text { Career }\end{array}$} & lower than 1 year & 14 & 3.83 & & Sales & 117 & 31.967213 \\
\hline & 1 year $\sim 5$ years & 47 & 12.84 & & $\mathrm{HR}$ & 133 & 36.338798 \\
\hline & 5 year $\sim 10$ years & 63 & 17.21 & & Finance & 39 & 10.655738 \\
\hline & $\begin{array}{c}10 \text { years } \sim 15 \\
\text { years }\end{array}$ & 66 & 18.03 & & Planning & 41 & 11.202186 \\
\hline & over 15 years & 176 & 48.09 & & & & \\
\hline & Total & 366 & 100 & & Total & 366 & 100 \\
\hline
\end{tabular}

\subsection{Verification of Normality}

The structural equation model can satisfy the assumption of multivariate normal distribution and perform accurate statistical verification when each measure variable is normally distributed. Therefore, in this study, the measured values were reviewed with Kline (2005)'s criteria that these values should not exceed the absolute value of Skewness 3 and Kurtosis 8. Ultimately, the results of the analysis of the collected variables showed that Skewness did not exceed 3 with absolute values less than 0.54 , and Kurtosis was less than 0.37 , which did not exceed 8 , so it was confirmed that there was no problem in meeting the basic assumption of multivariate normal distribution. Therefore, it was clarified that the structural equation can be analyzed through the measured variables collected for this research (Table 3 ).

Table 3: Results of Verification of Normality

\begin{tabular}{|c|c|c|c|c|}
\hline Variables & M & SD & Skewness & Kurtosis \\
\hline Task Crafting & 3.67 & 0.52 & -0.03 & 0.25 \\
\hline Relation Crafting & 3.65 & 0.56 & -0.03 & 0.19 \\
\hline Cognitive Crafting & 3.84 & 0.57 & -0.17 & 0.37 \\
\hline Career Attitude & 3.78 & 0.47 & 0.05 & -0.02 \\
\hline Career Commitment & 3.82 & 0.74 & -0.54 & -0.05 \\
\hline Career Success & 2.78 & 0.53 & -0.17 & 0.08 \\
\hline
\end{tabular}

\subsection{Analysis Results of Reliability and Validity}

To secure the reliability and validity of the research model verification, the constructs used through exploratory and confirmatory factor analysis were analyzed. First, the exploratory factor analysis revealed that one variable of task crafting was not included because it did not have its composition, and one variable of career commitment was also excluded. Therefore, as excluding the missing variables and conducting confirmatory factor analysis in Table 4, the factor loading values of the measured variables were analyzed mostly over 0.6 , which identifies they could be used as latent variables. Also, according to the criteria presented by Bhatnagar, Kim, and Many (2014), it was confirmed that all constructs are over 0.799 in the case of the composite reliability and that it meets the threshold condition if it is over 0.7 or closer. According to Anderson and Gerbing (1988), the average variance extracted requires 0.5 or more, all of the constructs of this study were secured between $0.571-0.724$ in validity. In addition, Cronbach $\alpha$ values are all over 0.783 and had a convergent validity.

The correlation analysis was conducted to identify the discriminant validity between constructs and to examine the degree of cross correlation. Through the criteria suggested by Fornell and Larcker (1981), the square value of correlation coefficient was not higher than AVE. As a result of the analysis in Table 5, the square value of each correlation coefficient did not exceed AVE, so it was clearly presented that the discriminant validity of latent variables were secured to be utilized for analysis.

\subsection{Analysis Results of Structural Model}

The criteria of fit index were identified to confirm the suitability of model. Basically, $\mathrm{x} 2 / \mathrm{d} . \mathrm{f}=2.514$ met the standard of $1<x 2 /$ d.f $<3$. According to the criteria of $\mathrm{Hu}$ and Bentler (1999), the goodness-of-fit index(GFI) and the comparative fit index(CFI) can be judged to be excellent when these are all 8 or more, and this model presented the significant results of $\mathrm{GFI}=0.874$ and $\mathrm{CFI}=0.902$. According to the criteria presented by Brown (2014), the model fit indices were found to be suitable for the criteria, as AGFI $=0.842, \mathrm{NFI}=0.849$, and RESEA=0.064 (Table 6). 
Table 4: Results of Reliability and Convergent Validity Test

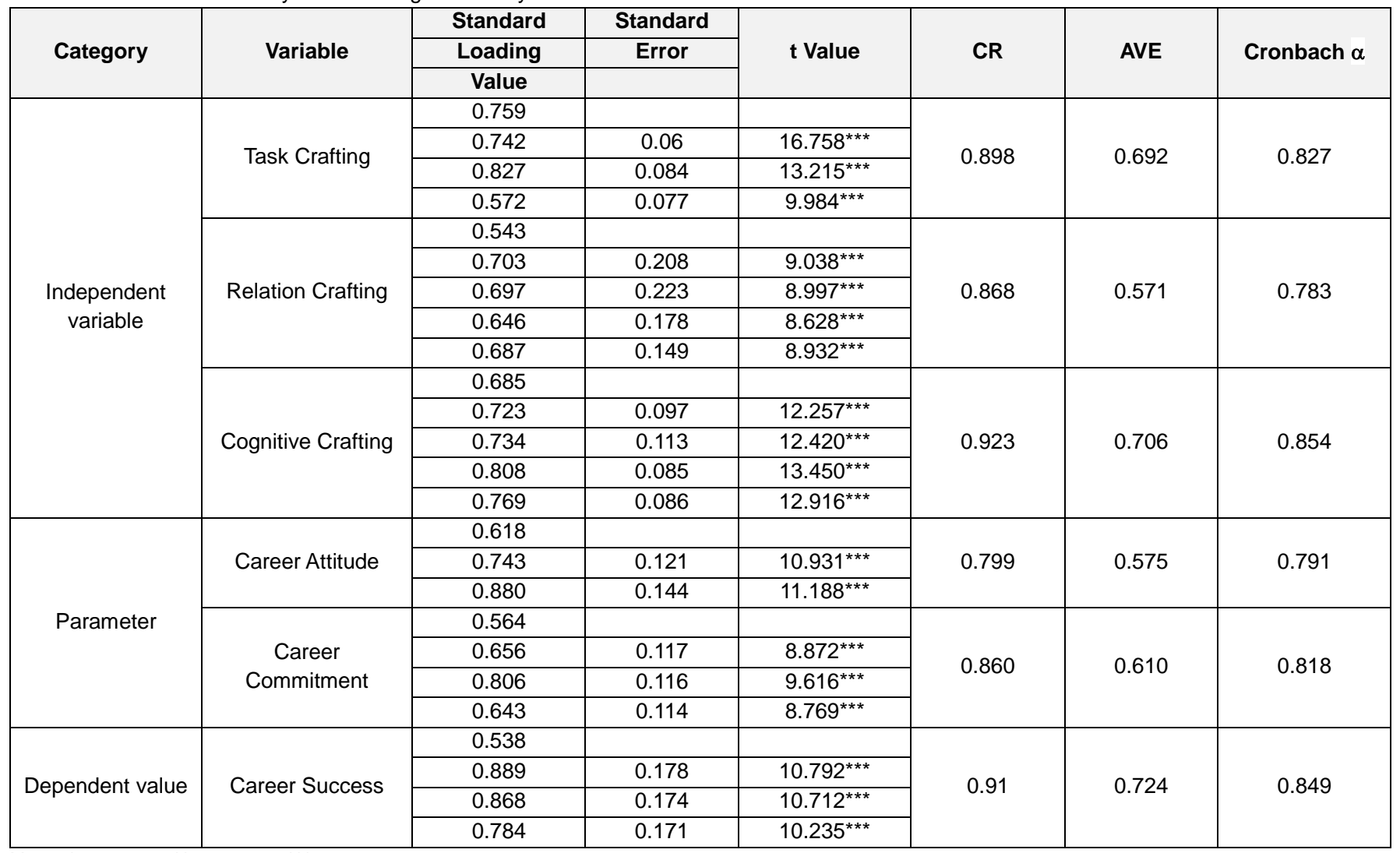

Note: ${ }^{*} p<0.05,{ }^{* *} p<0.01,{ }^{* \star *} p<0.001$

Table 5: Correlation Matrix and AVE

\begin{tabular}{|c|c|c|c|c|c|c|c|}
\hline Category & AVE & $\begin{array}{c}\text { Task } \\
\text { Crafting }\end{array}$ & $\begin{array}{c}\text { Relation } \\
\text { Crafting }\end{array}$ & $\begin{array}{c}\text { Cognitive } \\
\text { Crafting }\end{array}$ & $\begin{array}{c}\text { Career } \\
\text { Attitude }\end{array}$ & $\begin{array}{c}\text { Career } \\
\text { Commitment }\end{array}$ & $\begin{array}{c}\text { Career } \\
\text { Success }\end{array}$ \\
\hline Task Crafting & 0.692 & $\mathbf{0 . 8 3 1}$ & & & & & \\
\hline Relation Crafting & 0.571 & 0.491 & $\mathbf{0 . 7 5 6}$ & & & & \\
\hline Cognitive Crafting & 0.706 & 0.557 & 0.588 & $\mathbf{0 . 8 4 0}$ & & & \\
\hline Career Attitude & 0.575 & 0.406 & 0.253 & 0.453 & $\mathbf{0 . 7 8 1}$ & & \\
\hline Career Commitment & 0.610 & 0.477 & 0.333 & 0.449 & 0.414 & $\mathbf{0 . 7 5 8}$ & \\
\hline Career Success & 0.724 & 0.355 & 0.273 & 0.276 & 0.178 & 0.204 & $\mathbf{0 . 8 5 1}$ \\
\hline
\end{tabular}

Note: The numbers in bold are the AVE square root values of each variable

Table 6: Model fit Indices for the Structural Models

\begin{tabular}{|c|c|c|c|c|c|c|c|c|c|}
\hline Model & $x^{2}(d f)$ & $\begin{array}{c}\mathrm{X}^{2} \\
\text { /degrees } \\
\text { of } \\
\text { freedom }\end{array}$ & RMR & GFI & AGFI & NFI & RFI & CFI & RMSEA \\
\hline
\end{tabular}

As the results of the hypotheses verifications in Table 7, changing task boundaries (0.264) and changing cognitive boundaries (0.370) had a positive(+) impact on career attitude, and changing relation boundaries (-0.086) did not have any influence on career attitude. Also, changing task boundaries (0.338) and changing cognitive boundaries (0.265) had a positive(+) impact on career engagement, changing relation boundaries (0.015) did not have any influence on career engagement. Moreover, career attitude and career engagement gave a positive(+) effect on career success. Ultimately, hypothesis 1 , hypothesis 3 , hypothesis 4 , hypothesis 6 , hypothesis 7, and hypothesis 8 were selected, but hypothesis 2 and hypothesis 5 were rejected (Figure 2). 
Table 7: Results of Hypothesis Test

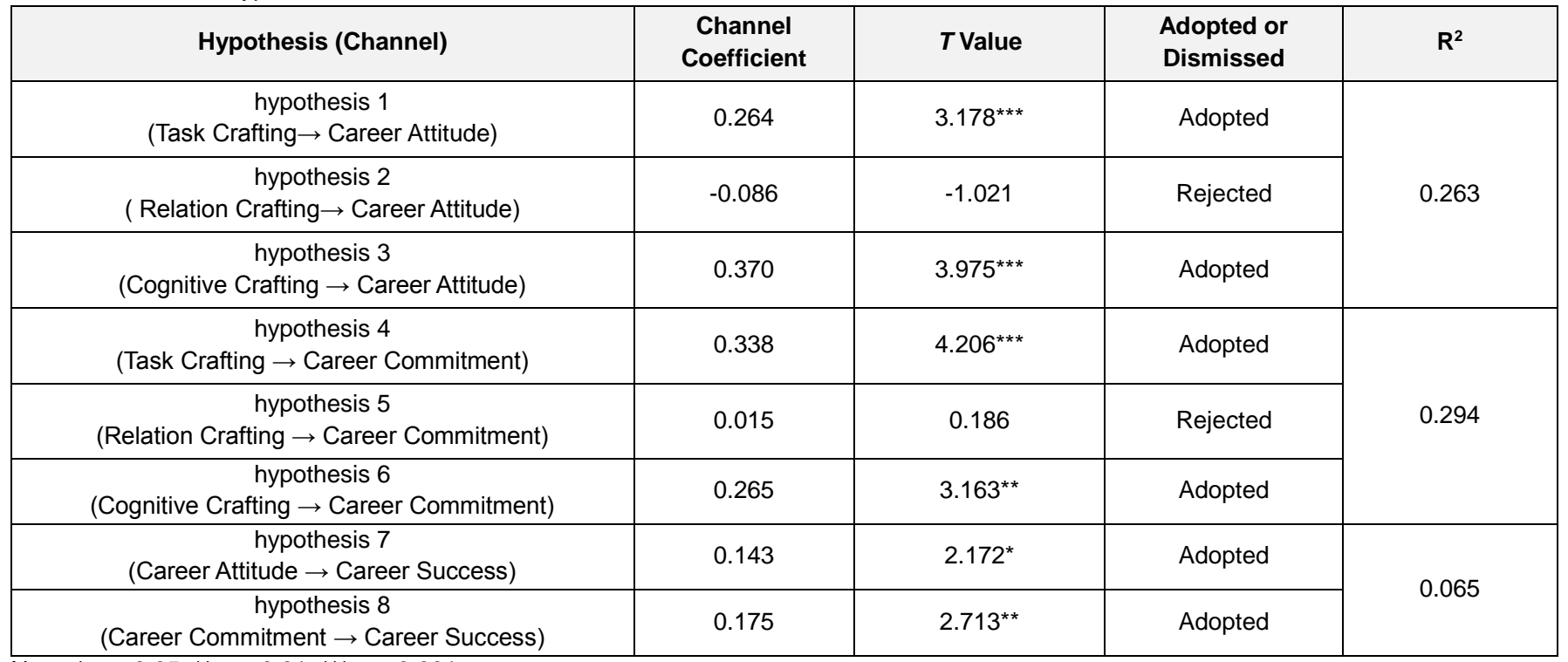

Note: ${ }^{*} p<0.05,{ }^{\star *} p<0.01,{ }^{* \star *} p<0.001$

Job Crafting

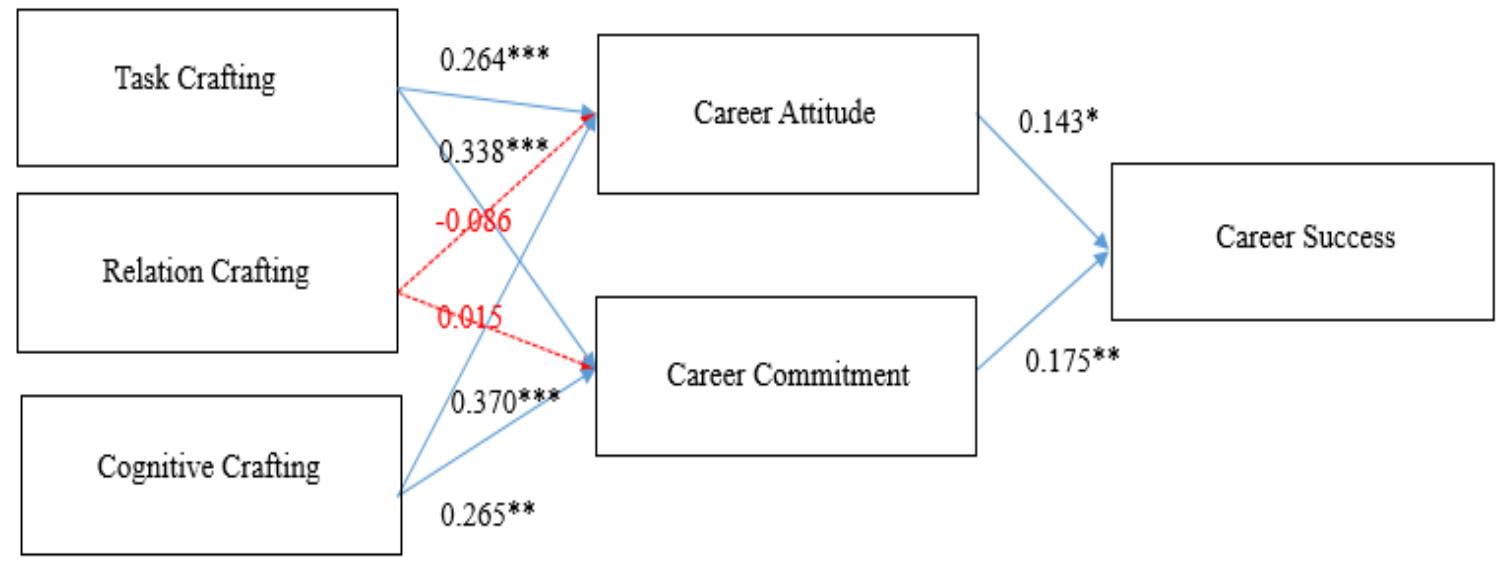

Figure 2: Research Model Result

\subsection{Mediated Effect}

Through the path analysis, the standard error was calculated using the direct effects and non-standard path coefficient, and the indirect effects and the total effect were analyzed to verify significance with bootstrap. In Table 8 , career attitude (0.120) and career commitment (0.117) were revealed to all have an impact on career success in the aspect of direct effect. Moreover, career attitude and career commitment were found to play a full mediating role between task crafting (0.097), relation crafting (0.010), cognitive crafting (0.099), and career success.
Table 8: Results of Mediated Effect

\begin{tabular}{|c|c|c|c|c|}
\hline $\begin{array}{c}\text { Dependent } \\
\text { Variable }\end{array}$ & $\begin{array}{c}\text { Explanatory } \\
\text { Variable }\end{array}$ & $\begin{array}{c}\text { Direct } \\
\text { Effect }\end{array}$ & $\begin{array}{c}\text { Indirect } \\
\text { Effect }\end{array}$ & $\begin{array}{c}\text { Total } \\
\text { Effect }\end{array}$ \\
\hline \multirow{4}{*}{$\begin{array}{c}\text { Career } \\
\text { Attitude }\end{array}$} & 0.120 & & 0.120 \\
\cline { 2 - 5 } Success & $\begin{array}{c}\text { Career } \\
\text { Commitment }\end{array}$ & 0.117 & & 0.117 \\
\cline { 2 - 5 } & Task Crafting & & 0.097 & 0.097 \\
\cline { 2 - 5 } & $\begin{array}{c}\text { Relation } \\
\text { Crafting }\end{array}$ & & 0.010 & 0.010 \\
\cline { 2 - 5 } & $\begin{array}{c}\text { Cognitive } \\
\text { Crafting }\end{array}$ & & 0.099 & 0.099 \\
\hline
\end{tabular}




\section{Conclusions}

This study aimed to empirically analyze whether task crafting, relation crafting and cognitive crafting, which are the three factors of job crafting, give an impact on career success through career attitude and career commitment based on the previous researches by Wrzesniewski and Detton (2001). In sum of the analysis results, first, the task crafting and cognitive crafting of multinational employees were shown to have an influence on career attitude, but relation crafting did not have any impact on career. This seems to be due to the performance management-oriented organizational culture of multinational corporations rather than relationship-oriented, and it can be interpreted that the employees have self-directed career attitude through a method of showing visible performance based on their given jobs rather than having individual career management attitude through relationships between departments, organizational members, and supervisors.

Second, the task crafting and cognitive crafting of multinational employees were found to have an impact on career commitment, and it presents the same result of the research (Park \& Sohn, 2018), which the employees have a negative effect and cannot engage in their job commitment when their cognitive crafting of job crafting is low. In contrast, relation crafting was shown to have any impact on career, but this result was analyzed to show different aspects from the study on the job commitment and career commitment through relation crafting which strengthens relationships with people ( $\mathrm{Lu}$ et al., 2014). The reason for these results can be regarded as the results of the organizatio0nal culture of multinational corporations. Because the multinational corporations have a horizontal and individual-centered culture, it can be interpreted that employees are more likely to perform given tasks rather than engaging in career commitment through relationshiporiented crafting in job crafting, and it can be interpreted that the effort to derive the outcomes in various ways and the career commitment through cognition are more strongly revealed.

Third, the factor that has the greatest influence on career commitment when targeting multinational employees is task crafting, and the career attitude showed a difference by cognitive crafting. It presents that the work commitment and experience value have a great impact on career commitment, but the different impacts on career attitude depend on how the members recognize and understand their works. Also, career commitment has a greater effect on the multinational employees than career attitude, which indicates that task crafting can be more powerful for career success than cognitive crafting.

This study can suggest three implications according to the study results. First, as the recent tendency of career management has changed, companies have supported progressive career management and development of their employees internally. Therefore, strengthening job crafting is an effective activity not only to improve the work efficiency of the organizations but also to improve the job satisfaction and wellbeing of their employees, so it is necessary to seek strategic implementation plans for job crafting in the organizational aspect. Then, it is possible to design programs that can enhance in community activities or business processes without defining job crafting as an individual activity of employees.

Second, in the case multinational corporations, the design for job crafting activities regarding these environments can be considered because various collaborations and tasks are carried out within their global networks. Especially, as the results of the analysis show that task crafting has a great impact on the multinational members, it is possible to consider job management strategies such as self-directed project performance and new job support that can induce career development.

Lastly, since multinational employees have an organizational and cultural feature that make the members to frequently leave their jobs, they strongly present protean career attitude through self-direction or value orientation in particular. Therefore, it is necessary to provide a management program in the aspect of cognitive crafting in order to manage and control such career attitude toward organizational citizenship behavior. In conclusion, through the establishment of value and the improvement of understanding on job and organization that can affect the outcomes of work, the strategic organization management can be discussed that can reduce the gap between the subjective organizational members' recognition and consensus and the organizational goals and can prosper alongside.

Today, as the management environment surrounding organizations has rapidly changed, a new perspective on career is required not only for the organizations but also for the individuals. Also, the relationship between individuals and organizations has changed. Organizations have been as difficult to keep taking responsibility for individual careers, like what they did in the past, and they emphasize that individuals have the capacity to take responsibility for their own careers (Moon \& Choi, 2012). Therefore, organizational members have paid a lot of attention not only to organizational commitment but also to individual career development (Hall, Waddell, Donner, \& Wheeler, 2004), In this respect, this study has the significance of defining the detailed factors of job crafting, which give an impact on career attitude, career commitment, and career success, and suggesting the empirical analysis results.

Nevertheless, this study has the following limitations. First, this study has the limit that it did not consider the specificity of multinational corporations as designing the hypotheses with the three factors of task crafting, relation crafting and cognitive crafting of job crafting. It is necessary to conduct the future research to empirically identify the connection of career success depending on the factors related to job crafting of multinational employees as applying qualitative researches. Second, this study has a limit in the interpreting into the generalized result of 
representing multinational employees as analyzing the survey data for the organizational members of multinational companies in South Korea. It is necessary to make effort to draw in-depth research results as applying the more generalized outcomes and then comparative analysis outcomes by corporation, through the expansion of companies by continent and country, in the further researches. Finally, this study did not apply detailed consideration factors for the characteristics and sizes of multinational corporations and the job positions of organizational members. Since career management can present a lot of differences according to tasks and job positions, it is necessary to consider the more detailed effect of job crafting and the relation with career management through the comparative analysis of the research subjects by particular categories.

\section{References}

Abele, A. E., \& Spurk, D. (2009). The longitudinal impact of self-efficacy and career goals on objective and subjective career success. Journal of Vocational Behavior, 74(1), 53-62.

Adya, M., \& Kaiser, K. M. (2005). Early determinants of women in the IT workforce: A model of girls' career choices. Information Technology \& People, 18(3), 230259.

Akkermans, J., \& Tims, M. (2017). Crafting your career: How career competencies relate to career success via Job Crafting. Applied Psychology, 66(1), 168-195.

Anderson, J. C., \& Gerbing, D. W. (1988). Structural equation modeling in practice: $\mathrm{A}$ review and recommended two-step approach. American Psych Logical Association, 103(3), 411-423.

Arthur, M. B., \& Rousseau, D. M. (1996). A career lexicon for the 21st century. Academy of Management Perspectives, 10(4), 28-39.

Arthur, M. B., Khapova, S. N., \& Wilderom, C. P. (2005). Career success in a boundaryless career world. Journal of Organizational Behavior, 26(2), 177-202.

Aryee, S., \& Chay, Y. W. (1994). An examination of the impact of career- oriented mentoring on work commitment attitudes and career satisfaction among professional and managerial employees. British Journal of Management, 5(4), 241-249. https://doi.org/10.1111/j.1467-8551.1994.tb00076.x

Bakker, A. B., Tims, M., \& Derks, D. (2012). Proactive personality and job performance: The role of Job Crafting and work engagement. Human Relations, 65(10), 1359-1378.

Bakker, A. B., Rodríguez-Muñoz, A., \& Sanz-Vergel, A. I. (2016). Modelling Job Crafting behaviours: Implications for work engagement. Human Relations, 69(1), 169-189. https://doi.org/10.1177/0018726715581690

Ballout, H. I. (2009). Career commitment and career success:
Moderating role of self-efficacy. Career Development International, 14(7), 655-670.

Baruch, Y. (2001). The status of research on teleworking and an agenda for future research. International Journal of Management Reviews, 3(2), 113-129.

Berg, J. M., Dutton, J. E., \& Wrzesiewski, A. (2008). What is Job Crafting and why does it matter? The University of Michigan. Retrieved August 1, 2019, from https://positiveorgs.bus.umich.edu/wpcontent/uploads/What-is-Job-Crafting-and-Why-Does-itMatter1.pdf

Berg, J. M., Wrzesniewski, A., \& Dutton, J. E. (2010). Perceiving and responding to challenges in job crafting at different ranks: When proactivity requires adaptivity. Journal of Organizational Behavior, 31, 158-186.

Bhatnagar, R., Kim, J., \& Many, J. E. (2014). Candidate surveys on program evaluation: Examining instrument reliability, validity and program effectiveness. American Journal of Educational Research, 2(8), 683-690.

Black, J. S., \& Ashford, S. J. (1995). Fitting in or making jobs fit: Factors affecting mode of adjustment for new hires. Human Relations, 48(4), 421-437. https://doi.org/10.1177/001872679504800407

Blau, G. J. (1989). Testing the generalizability of a career commitment measure and its impact on employee turnover. Journal of Vocational Behavior, 35(1), 88-103.

Briscoe, J. P., \& Hall, D. T. (2006). The interplay of boundaryless and protean careers: Combinations and implications. Journal of Vocational Behavior, 69(1), 418.

Campion, M. A., \& McClelland, C. L. (1993). Follow-up and extension of the interdisciplinary costs and benefits of enlarged jobs. Journal of Applied Psychology, 78(3), 339-351.

Carson, K. D., \& Bedeian, A. G. (1994). Career commitment: Construction of a measure and examination of its psychometric properties. Journal of Vocational Behavior, 44(3), 237-262.

Chen, C. Y., Yen, C. H., \& Tsai, F. C. (2014). Job Crafting and job engagement: The mediating role of person-job fit. International Journal of Hospitality Management, 37, 21-28.

De Vos, A., \& Segers, J. (2013). Self-directed career attitude and retirement intentions. Career Development International, 18(2), 155-172.

Demerouti, E., Bakker, A. B., \& Gevers, J. M. (2015). Job Crafting and extra-role behavior: The role of work engagement and flourishing. Journal of Vocational Behavior, 91, 87-96.

Doherty, N., Dickmann, M., \& Mills, T. (2011). Exploring the motives of company-backed and self-initiated expatriates. The International Journal of Human Resource Management, 22(3), 595-611. https://doi.org/10.1080/09585192.2011.543637

Dries, N., Van Acker, F., \& Verbruggen, M. (2012). How boundaryless are the careers of high potentials, key experts and average performers? Journal of Vocational 
Behavior, 81(2), 271-279.

Evers, A., \& Sieverding, M. (2014). Why do highly qualified women (still) earn less? Gender differences in long-term predictors of career success. Psychology of Women Quarterly, 38(1), 93-106.

Fornell, C., \& Larcker, D. F. (1981). Evaluating Structural Equation Models with unobservable variables and measurement error. Journal of Marketing Research, 18(1), 39-50.

Fried, Y., Grant, A. M., Levi, A. S., Hadani, M., \& Slowik, L. H. (2007). Job design in temporal context: A career dynamics perspective. Journal of Organizational Behavior, 28(7), 911-927.

Gattiker, U. E., \& Larwood, L. (1986). Subjective career success: A study of managers and support personnel. Journal of Business and Psychology, 1(1), 78-94.

Ghitulescu, B. E. (2013). Making change happen: The impact of work context on adaptive and proactive behaviors. The Journal of Applied Behavioral Science, 49(2), 206-245.

Griffin, M. A., Neal, A., \& Parker, S. K. (2007). A new model of work role performance: Positive behavior in uncertain and interdependent contexts. Academy of Management Journal, 50(2), 327-347

Grant, A. M., \& Ashford, S. J. (2008). The dynamics of proactivity at work. Research in Organizational Behavior, 28, 3-34.

Grant, A. M., Parker, S., \& Collins, C. (2009). Getting credit for proactive behavior: Supervisor reactions depend on what you value and how you feel. Personnel Psychology, 62(1), 31-55. https://doi.org/10.1111/j.17446570.2008.01128.x

Hall, D. T. (2002). The protean career: A quarter-century journey. Journal of Vocational Behavior, 65, 1-13

Hall, L. M., Waddell, J., Donner, G., \& Wheeler, M. M. (2004). Outcomes of a career planning and development program for registered nurses. Nursing Economics, 22(5), 231-245.

Hall, D. T., \& Heras, M. L. (2010). Reintegrating job design and career theory: Creating not just good jobs but "smart" jobs. Journal of Organizational Behavior, 31(2/3), 448462.

Hallenbeck, G. (2016). Learning agility: Unlock the lessons of experience. Greensboro, NC; Center for Creative Leadership.

Heslin, P. A. (2005), Conceptualizing and evaluating career success. Journal of Organizational Behavior, 26, 113136.

Hu, L. T., \& Bentler, P. M. (1999). Cutoff criteria for fit indexes in covariance structure analysis: Conventional criteria versus new alternatives. Structural Equation Modeling: A Multidisciplinary Journal, 6(1), 1-55.

Hur, J., Jung, J. H., \& Kang, S. A. (2019). Study on the relationship among empowering leadership, job crafting, job engagement and innovative behavior: Focused on restaurant industry employees. Culinary Science \& Hospitality Research, 25(7), 70-80.
Ilgen, D. R., \& Hollenbeck, J. R. (1992). The structure of work: Job design and roles. In M. Dunnette and L. Hough (Eds.), Handbook of industrial organizational psychology. Palo Alto, CA: Consulting Psychologists Press.

Kidd, J. M., \& Green, F. (2006). The careers of research scientists: Predictors of three dimensions of career commitment and intention to leave science. Personnel Review, 35(3), 229-51.

Kim, C. H., \& Shim, W. S, (2012). A study on the influence and process of leader's sincerity on subordinates' craft crafting. Organization and Human Resources Research, 34, 131-162.

Kim S. Y., Bae S. H., Kim H. G., \& Ahn S. I. (2016). The effect of job crafting behavior on innovation behavior: Focused on the mediating effect of job enthusiasm. Human Resource Management Research, 23(5), 1-26.

Kim, M., \& Beehr, T. A. (2018). Can empowering leaders affect subordinates' well-being and careers because they encourage subordinates' job crafting behaviors? Journal of Leadership \& Organizational Studies, 25(2), 184-196.

Kline, R. (2005). Methodology in the social sciences: Principles and practice of structural equation modeling (2nd ed.). New York, NY: Guilford Press

Ko, I. (2012). Crafting a job: Creating optimal experiences at work. Claremont, CA: The Claremeont Graduate University.

Kossek, E. E., Roberts, K., Fisher, S., \& Demarr, B. (1998). Career self-management: A quasi-experimental assessment of the effects of a training intervention. Personnel Psychology, 51, 935-962.

Kostova, T., \& Roth, K. (2002). Adoption of an organizational practice by subsidiaries of multinational corporations: Institutional and relational effects. Academy of Management Journal, 45(1), 215-233.

Lee, K. H., \& Lee, Y. M. (2015). The influence of borderless career attitudes on workplace movement-focused on the comparison between Korean and foreign companies. Human Resource Management Research, 22(4), 5-246.

Lim, M. K. (2016). Effects of changes in the calling of new employee. Corporate Management Research, 56, 181206.

Lim, Y. K., Ha, Y. J., Oh, D. J., \& Son. Y. W. (2014). Korean version of crafting (JC .Q-K) validation study. Corporate Management Study, 56(4), 181-206.

Lent, R. W., Ireland, G. W., Penn, L. T., Morris, T. R., \& Sappington, R. (2017). Sources of self-efficacy and outcome expectations for career exploration and decision-making: A test of the social cognitive model of career self-management. Journal of Vocational Behavior, 99, 107-117.

Lu, C. Q., Wang, H. J., Lu, J. J., Du, D. Y., \& Bakker, A. B. (2014). Does work engagement increase person-job fit? The role of job crafting and job insecurity. Journal of Vocational Behavior, 84(2), 142-152.

Lyons, P. (2005). Enhancing human resources competitiveness using skill charting methods. Advances 
in Competitiveness Research, 13(1), 87-94.

Moon, J. S., \& Choi, S. B. (2012). The effect of career management behavior, organizational career development support and career performance on organizational commitment. Management Education Research, 27, 431-457.

$\mathrm{Na}$, G. H. (2015). Role of career commitment in the relationship between career planning and career success. Professional Management Research, 18(1), 47-67.

Nam, J. S. (2014). Subjective career success of large corporate office workers and the hierarchical relationship of individual and organizational characteristics (Doctoral dissertation). Seoul National University, Seoul, Korea.

Noordin, F., Williams, T., \& Zimmer, C. (2002). Career commitment in collectivist and individualist cultures: A comparative study. International Journal of Human Resource Management, 13(1), 35-54.

Pan, J., \& Zhou, W. (2015). How do employees construe their career success: An improved measure of subjective career success. International Journal of Selection and Assessment, 23(1), 45-58. https://doi.org/10.1111/ijsa.12094

Park, H. K. (2015). Job re-creation and hierarchical relationship between individual and team level variables of workers in large corporations (Doctoral dissertation). Seoul National University, Seoul, Korea.

Park, J., \& Sohn, Y. W. (2018). Is it happy to work with leaders viewing their work as a calling? Korean Journal of Industrial and Organizational Psychology, 31(2), 353385.

Petrou, P., Demerouti, E., \& Schaufeli, W. B. (2015). Job Crafting in changing organizations; Antededents and implications for exhaustion and performance. Journal of Occupational Health Psychology, 20(4), 470-480.
Petrou, P., Demerouti, E., Peeters, M. C., Schaufeli, W. B., \& Hetland, J. (2012). Crafting a job on a daily basis: Contextual correlates and the link to work engagement. Journal of Organizational Behavior, 33(8), 1120-1141.

Richardson, J., \& Mallon, M. (2005). Career interrupted? The case of the self-directed expatriate. Journal of World Business, 40(4), 409-20.

Seibert, S. E., \& Kraimer, M. L. (2001). The five-factor model of personality and career success. Journal of Vocational Behavior, 58, 1-21.

Seibert, S. E., Kraimer, M. L., \& Liden, R. C. (2001). A social capital theory of career success. Academy of Management Journal, 44(2), 219-237.

Slemp, G. R., \& Vella-Brodrick, D. A. (2013). The Job Crafting Questionnaire: A new scale to measure the extent to which employees engage in Job Crafting. International Journal of Wellbeing, 3(2), 126-146.

Tims, M., \& Bakker, A. B. (2010). Job crafting: Towards a new model of individual job redesign. SA Journal of Industrial Psychology, 36(2), 1-9.

Tims, M., Bakker, A. B., \& Derks, D. (2015). Job crafting and job performance: A longitudinal study. European Journal of Work Organizational Psychology, 24(6), 914928. https://doi.org/10.1080/1359432X.2014.969245

Wrzesniewski, A., \& Dutton, J. E. (2001). Crafting a job: Revisioning employees as active crafters of their work. Academy of Management Review, 26, 179-201.

Wrzesniewski, A., LoBuglio, N., Dutton, J. E., \& Berg, J. M. (2013). Job crafting and cultivating positive meaning and identity in work. Positive Organizational Psychology, 1, 281-302.

Yan, X., Su, J., Wen, Z., \& Luo, Z. (2017). The role of work engagement on the relationship between personality and job satisfaction in Chinese nurses. Current Psychology, $38(1), 1-6$. 